\title{
EGF stimulates Pit-1 independent transcription of the human prolactin pituitary promoter in human breast cancer SK-BR-3 cells through its proximal AP-1 response element.
}

Isabelle Manfroid ${ }^{a}$, Cécile Van de Weerdt, Ariane Baudhuin, Joseph A. Martial, Marc Muller*

Laboratoire de Biologie Moléculaire et de Génie Génétique, Université de Liège, Institut de Chimie B6, B-4000 Sart-Tilman, Belgium

a Laboratoire de Génétique et Physiologie du Développement, UMR 9943 CNRS-Université, IBDM-INSERM-Université de la Méditerranée, Campus de Luminy, Case 907, F-13288 Marseille, Cedex 09, France

* corresponding author

Tel +3243664437 Fax +32 4 3662968

E-Mail:m.muller@ulg.ac.be

Running title: HPRL gene regulation in mammary cells

Keywords: prolactin, mammary cells, regulation, Pit-1, AP-1, EGF, JNK 


\section{ABSTRACT}

Normal and neoplastic human mammary gland cells are targets for the proliferative action of prolactin. These cells also synthesize prolactin, thereby inducing an autocrine/paracrine proliferative loop.

We present the first extensive analysis of the transcriptional regulation of the human prolactin gene (hPRL) in human mammary tumor cells, SK-BR-3. We show that the pituitary promoter is functional in these cells in the absence of the pituitaryspecific factor Pit-1. Expression of exogenous Pit-1 or EGF treatment stimulates the transfected hPRL pituitary promoter and the endogenous hPRL expression. EGF stimulation is mediated by increased synthesis of c-fos and c-jun, resulting in AP-1 binding to the proximal hPRL pituitary promoter. This regulation involves the EGF receptor, possibly ErbB2 that is highly expressed in SKBR-3 cells, and a PI3K/JNK pathway.

The stimulation of hPRL gene transcription by EGF in mammary cells may include hPRL in a complex regulatory network controlling growth of human mammary cells. 


\section{INTRODUCTION}

Prolactin (PRL) is a polypeptide hormone mostly produced by the adeno-pituitary gland where its expression is modulated by numerous extracellular signals, e.g. TRH, EGF, thyroid hormones, glucocorticoids, estrogens and by second messengers Ca2+ and CAMP (Peers et al., 1990, 1991; Berwaer et al., 1991; 1993; Hoggard et al., 1991; Nalda et al., 1997; Pernasetti et al., 1997; Van De Weerdt et al., 2000; reviewed in Muller et al., 1998). It displays many biological activities triggered through binding to its specific transmembrane receptor (PRLR). In mammals, PRL mainly promotes growth and development of the mammary gland, as well as milk production and secretion (Shiu et al., 1987). PRL is also involved in human mammary tumor development (reviewed in Llovera et al., 2000a; Clevenger et al., 2003) and acts as a mitogen on several human breast cancer lines (Biswas et al., 1987; Fuh and Vonderhaar, 1995; Ginsburg et al., 1995; Llovera et al., 2000b; Acosta et al., 2003; Schroeder et al., 2003). Epidemiological studies suggest a role for PRL in human breast cancer promotion and growth (Holtkamp et al., 1984; Bhatavdekar et al., 1990; Hankinson et al., 1999). However, anticancer therapies designed to block expression and secretion of pituitary lactogenic hormones (PRL and growth hormone) had little effect on the course of the disease (Anderson et al., 1993). One hypothesis that could account for this observation is a local expression of PRL acting through an autocrine/paracrine loop within the human breast (Clevenger et al., 1995; Ben-Jonathan et al., 2002; Clevenger et al., 2003).

In addition to the pituitary gland, synthesis of PRL mRNA has been observed in $\mathrm{T}$ lymphocytes and decidualized endometrium (DiMattia et al., 1988; Gellersen et al., 1989; Pellegrini et al., 1992). Moreover, PRL mRNAs have also been detected in human mammary tissues (Fields et al., 1993; Clevenger et al., 1995; Reynolds et al., 1997). Expression of the PRL gene was observed 
in both normal and neoplastic human breast tissue (Shaw-Bruha et al., 1997) and in human mammary cell lines derived from breast epithelium carcinoma (Clevenger et al., 1995; Ginsburg and Vonderhaar, 1995; Shaw-Bruha et al., 1997). The observation that hPRL antagonists blocked cultured mammary tumor cell growth further supports the existence of an autocrine/paracrine loop (Fuh and Wells, 1995; Ginsburg and Vonderhaar, 1995; Chen et al., 2002 ) .

In pituitary, the hPRL mRNA starts with exon $1 \mathrm{~b}$ at the pituitary start site and transcription is controlled by the pituitary promoter, extending to possibly $5.8 \mathrm{~kb}$ of upstream region (Truong et al, 1984). The pituitary promoter contains many binding sites for the pituitary-specific transcription factor Pit-1 and several binding sites for ubiquitous transcription factors (Van de Weerdt et al., 2000), the most prominent being the estrogen receptor. Recently, AP-1 was found to be involved in the control of the human pituitary promoter in response to MAPK ERKs activation (Caccavelli et al., 1998; Manfroid et al., 2001). Pit-1 independent non-pituitary hPRL gene transcription was reported in lymphocytes and endometrial cells (Gellersen et al., 1994). Transcription of hPRL mRNA in lymphocytes and decidua is driven by an alternative, decidual/lymphoid promoter. A different start site is used, located $5.8 \mathrm{~kb}$ upstream from the pituitary start site, and the spliced RNA contains an additional exon (exon 1a) (Dimattia et al., 1990). Thus, the 5'-UTR sequence in decidual/lymphoid cells is about 150 nucleotides longer than the pituitary 5'-UTR and both proteins are identical (Gellersen et al., 1994). Blood cell and endometrial hPRL expression was shown to be controlled by CAMP or CAMP and progesterone respectively (Gellersen et al., 1994; Telgmann et al., 1997; Pohnke et al., 1999; Reem et al., 1999; Gerlo et al., 2003), the latter involving transcription factors of the Ets family (Brar et al., 2002 ). Few studies are available concerning the promoter used in mammary cells and they give conflicting results. 
Decidual/lymphoid type PRL transcripts were detected in some, but not all mammary tissues and cells (Shaw-Bruha et al., 1997), while a study performed in goat and sheep showed that the size of the mammary gland mRNA is similar to the pituitary hPRL mRNA (Le Provost et al., 1994).

Here, we present an extensive study of the expression of the hPRL gene in the luminal epithelial mammary tumor cell line SKBR-3. Interestingly, our data argue for the use of the pituitary promoter, and not the decidual/lymphoid promoter, in these nonpituitary cells, although no Pit-1 mRNA was detected. Both the transfected and the endogenous pituitary promoter are activated by epidermal growth factor (EGF) and exogenous Pit-1. EGFstimulation involves a PI3K/JNK pathway leading to binding of a c-jun/c-fos complex to an AP-1 site in the hPRL proximal pituitary promoter.

\section{MATERIALS AND METHODS}

\section{Reagents}

EGF, SB203580 and Tyrphostin AG1478 were purchased at Sigma Chemical Co (St. Louis, MO). Bisindolylmaleimide, Wortmannin and N-acetyl-S-farnesyl-L-cysteine were provided by ICN Pharmaceuticals Inc. (Costa Mesa, CA).

Specific anti- c-jun, -JunB, JunD, -C-fos, -FosB, -Fra-1 antibodies are commercialized by Santa Cruz Biotechnology (Santa Cruz, CA). Monoclonal anti-Oct-1 (Lai and Herr, 1992) was a kind gift from W. Herr (Cold Spring Harbor, NJ).

Rabbit polyclonal antibodies were obtained (Eurogentec, Seraing, Belgium) using bacterially expressed and purified hPRL $16 \mathrm{kDa}$ fragment (Struman et al., 1999) and shown to recognize the $23 \mathrm{kDa}$ hPRL. These and monoclonal anti-phospho-JNK (Santa Cruz Biotechnology, Santa Cruz, CA) were used for immunofluorescence staining analysis. Bacterially expressed and purified $23 \mathrm{kDa} h P R L$ was obtained as described (Paris et al., 1990). 


\section{Cell culture}

Human SK-BR-3, derived from a breast adenocarcinoma (American Type Culture Collection), and lymphoid Jurkat cells were propagated in RPMI, HeLa cells (human cervix adenocarcinoma) in DMEM respectively containing $10 \%$ heat-inactivated fetal bovine serum and 1\% penicillin/streptomycin (Gibco-BRL, Grand Island, NY) . Human pituitary GX cells (Chomczynski et al., 1993), kindly provided by Dr. Frohman (Los Angeles, CA), were grown in MEM containing $10 \%$ horse serum. Growth conditions for rat pituitary GH3B6 cells were previously described (Caccavelli et al., 1998).

\section{Plasmids and oligonucleotides}

3474P-Luc, 1750P-Luc， 740P-Luc， 250P-Luc， 164P-Luc， 40P-Luc contain successive $5^{\prime}$ deletions of the hPRL pituitary promoter driving the luciferase reporter gene. 3474P-Luc was obtained by insertion of the SstI/BglII fragment from 3474PRLCAT (Peers et al., 1990) into the corresponding sites of 250P-Luc (Poncelet et al., 1996). 1750P-Luc and 740P-Luc were obtained from 3474P-Luc by excising respectively the AflII/SstI and HindIII/SstI fragments followed by Klenow fill-in and religation. $3474 \mathrm{P} 1$,Pit$1 \mathrm{~m}-$ Luc and $3474 \mathrm{P} 1, \mathrm{AP} 1 \mathrm{~m}-L u c$ were obtained by joining the SstI/BsmI fragment from $3474 \mathrm{P}-\mathrm{Luc}$ to a BsmI/BglII fragment $(-64 /+14)$ obtained by PCR respectively from 164P1,Pit-1m-Luc or 164P1,AP1mLuc (Caccavelli et al., 1998) using the appropriate primers and inserting them into the SstI/BglII digested pXP2 empty vector. 164P-Luc and 40P-Luc and the expression plasmid for human Pit-1 (pcDNA3-hPit-1) were previously described (Caccavelli et al., 1998). The 1a1878PRL-Luc constructs contain the lymphoid/decidual promoter (Berwaer et al., 1994) driving the luciferase gene.

RT-PCR and PCR were performed using the following primers in the hPRL mRNA (the positions are given relative to the ATG in the decidual hPRL CDNA sequence (Gellersen et al., 1989)): forla (positions $-132 /-105$ in exon $1 a$ ), for $1 b$ (positions $-52 /-27$ in 
exon 1b), for3 (positions $276 / 299$ in exon 3), for 4 (positions $340 / 365$ in exon 4) for reverse primers, and rev2 (positions $118 / 142$ in exon 2), rev5 (positions $496 / 525$ in exon 5 ) as reverse primers. Primers for3, for 4 and rev5 allow amplification of rat and human hPRL CDNA.

Primers designed in hPit-1 CDNA are PITfor (positions $-13 /+9$ in exon 1) and PITrev (positions 353/378 in exon 2), positions are also given relative to the ATG:

tubFOR: aagaagtccaagctggagttc

tubREV: gttggtctggaattctgtcag

forla: gagacaccaagaagaatcggaacatac

forlb: agacttccagatcttctctggtgaag

rev2: tcaaacaggtctcgaagggtcacct

for3: acccccgaagacaaggagcaagcc

for 4 : gcatattgcgatcctggaatgagcc

rev5: gtagatctcattttctttggtttcaggat

PITfor: ctctctcttgtgggaatgagttgc

PITrev: gagaatccatgtctattggctcttcc

Oligonucleotides P1, AP-1, P1(Pit-1)m, P1(AP-1)m, Oct-1 and NF-Y were described (34).

\section{RT-PCR and PCR}

Poly-A RNAs were prepared using the QuickPrepTM Micro mRNA purification kit (Amersham Pharmacia Biotech Inc, NJ). RT-PCR reactions were performed with the Titan One Tube RT-PCR kit (Roche Diagnostics Corporation, IN) with $250 \mathrm{ng}$ of mRNA as recommended by the manufacturer. Briefly, CDNA synthesis was carried out at $55^{\circ} \mathrm{C}$ for $30 \mathrm{~min}$, followed by $40 \mathrm{PCR}$ cycles $\left(94^{\circ} \mathrm{C}\right.$ $\left.45 \mathrm{sec}, 64^{\circ} \mathrm{C} 30 \mathrm{sec}, 68^{\circ} 30 \mathrm{sec}\right)$. Where indicated, a second PCR was performed as follows: sample (from the first RT-PCR) dilution 1/500, $200 \mu \mathrm{M}$ dNTP, 10 pmoles primers, $0.25 \mathrm{U}$ Taq polymerase Gold (Perkin Elmer, Life Sciences, Boston, MA), 1x buffer, $1.5 \mathrm{mM}$ $\mathrm{MgCl} 2$ in $50 \mu \mathrm{l}$. An initial $7 \mathrm{~min}$ step at $95^{\circ} \mathrm{C}$ (DNA denaturation and Gold Taq polymerase activation) followed by 35 cycles $\left(94^{\circ} \mathrm{C}\right.$ 
$45 \mathrm{sec}, 64^{\circ} \mathrm{C} 30 \mathrm{sec}$ and $\left.68^{\circ} \mathrm{C} 30 \mathrm{sec}\right) \cdot 10 \mu \mathrm{l}$ were loaded on a $3 \%$ agarose ethidium bromide stained gel and revealed with UV light.

For semi-quantitative RT-PCR, the linear range of the PCR amplification reaction was determined for control and EGF-treated cell samples using $0.1 \mathrm{ng} \mathrm{mRNA}$ and the parameters detailed above, testing the amount of amplified product every 3 cycles. A similar approach was used for $\alpha$-tubulin. The reactions were calibrated using $\alpha$-tubulin amplifications and the results for hPRL after equivalent numbers of cycles are shown. Quantification of the specific bands was performed using the NIH Image software.

\section{Transfections}

$3.10^{5}$ SK-BR-3 cells were plated in 6-well dishes the day before transfection. Transient transfections were performed using Lipofectamine PlusTM (Gibco-BRL, Grand Island, NY) with $2 \mu \mathrm{g}$ DNA as already described (Manfroid et al., 2001). The day following transfection, cells were treated with $50 \mathrm{ng} / \mathrm{ml} \mathrm{EGF}$, or with different inhibitors as indicated, diluted in the culture medium. 18 hrs later, the cells were harvested and the luciferase activities in cellular extracts were determined as described (Manfroid et al., 2001). The luciferase activities were normalized relative to the amount of total protein in the extracts, as measured using a standard colorimetric Bradford assay. Each transfection was performed in triplicate at least twice. The mean relative light units $\pm \mathrm{S} . \mathrm{D}$. are shown in Fig.2B and 2D. Fold inductions were calculated as the ratio between promoter activity in treated cells/ promoter activity in untreated cells. S.D. values were obtained accordingly.

\section{EMSAs and Western blots}

Nuclear protein extracts were prepared as previously described (34). For whole cell extracts, cells were lysed in $400 \mathrm{mM} \mathrm{KCl,}$ $20 \%$ glycerol, $20 \mathrm{mM}$ Hepes $\mathrm{pH}=7.8,2 \mathrm{mM}$ DTT, centrifuged for 30 min at $14000 \mathrm{rpm}$ and the supernatant collected. EMSAs and Western 
blot assays were performed as described (Caccavelli et al., $1998)$.

\section{Immunofluorescence}

For immunofluorescence staining analysis, $10^{6}$ cells were seeded in P30 dishes in culture medium. After $18 \mathrm{~h}$, the medium was replaced by medium containing $1 \%$ serum, then cells were grown for further $24 \mathrm{~h}$. For phospho-JNK analysis, cells were submitted for $30 \mathrm{~min}$ to several treatments as indicated and fixed in $4 \%$ paraformaldehyde. Cells were then stained with anti-phospho-JNK followed by Texas red-coupled anti-mouse secondary antibody (Amersham/Pharmacia Biotech Inc, NJ). For hPRL detection, $10^{6}$ cells were either mock transfected or transfected with $2 \mu \mathrm{g}$ pcDNA3-hPit-1 (Manfroid et al., 2001) using Lipofectamine Plus ${ }^{\mathrm{TM}}$. $24 \mathrm{~h}$ after transfection, cells were fixed and stained with antihPRL 16K. Fluorescein isothiocyanate (FITC)-coupled anti-rabbit was used as secondary antibody (Amersham Pharmacia Biotech Inc, NJ). Slides were examined using an Olympus BX60 microscope equipped with a ColorView8 device camera and analysis 3.0 (Soft Imaging System).

\section{RESULTS}

\section{Human SK-BR-3 mammary cells synthesize hPRL mRNA and protein}

The presence of hPRL protein in SK-BR-3 whole-cell extracts was assessed by Western blot assay (Fig. 1A). Extracts from PRLexpressing lymphoid Jurkat cells and from HeLa cells were used as positive and negative controls, respectively. A clear hPRL signal of apparent molecular weight $23-26 \mathrm{kDa}$ was detected in Jurkat and SK-BR-3 extracts. No hPRL was detected in Hela cell extracts, as expected. When defined amounts (200 and $500 \mathrm{ng})$ of bacterially expressed and purified hPRL protein were used as a standard, comparison of the signal intensities suggests that the amount of $\mathrm{hPRL}$ in $60 \mu \mathrm{g}$ of SK-BR-3 extracts is much lower than $200 \mathrm{ng}$. 
To ensure that hPRL is indeed synthesized in SK-BR-3 cells, the presence of hPRL mRNAs in mammary SK-BR-3 cells was assessed by RT-PCR using specific primers located in exons 3, 4 and 5 (see fig (B). As a positive control, two pituitary cell lines were used: human GX and rat GH3B6 cells. A 250 bp fragment was obtained with the primer pair for3/rev5 from GX, GH3B6 and SK-BR3 cells (Fig. 1C). To confirm the identity of this fragment, a second PCR reaction was performed on the RT-PCR samples with the internal forward primer for4 and rev5. A 185 bp fragment was obtained in each case (Fig. 1C). The PCR product obtained from SK-BR-3 cells was cloned for sequencing and was completely identical to the expected hPRL sequence (data not shown). No hPRL messenger was detected in HeLa cells, a human cervix cell line that does not express PRL. The $\alpha$-tubulin mRNA was used to control the RT-PCR reactions.

In human, two distinct hPRL gene promoters are used depending on the cell type: the pituitary promoter and the lymphocyte/decidual promoter. The mRNA transcribed from the lymphoid/decidual promoter is characterized by a 150 nucleotides extension in the 5'-untranslated region relative to the pituitary type transcript (Fig. 1B). To determine which type of hPRL mRNA is present in SK-BR-3 cells, RT-PCR reactions were performed using forward primers corresponding to the lymphoid/decidual exon la (forla) or to the common exon $1 \mathrm{~b}$ (for $1 \mathrm{~b}$ ) with a reverse primer localized in exon 2 (rev2) (Fig. 1D). Control reactions were performed on RNA from lymphoid Jurkat and pituitary GX cells. Both primer pairs generated the anticipated fragments in Jurkat cells, as expected for the presence of lymphoid type RNA, while hPRL mRNAs were amplified only with primers forlb/rev2 in pituitary GX cells, as expected from pituitary-type mRNA. In SKBR-3 cells, mRNA containing exon $1 b$, but not exon $1 a$ was detected, suggesting the use of the pituitary promoter in these mammary tumor cells. No RT-PCR fragment was obtained from the HeLa cell RNA (negative control). 
The hPRL pituitary promoter is transcriptionally active in SKBR-3 cells

To test for the transcriptional activity of the hPRL gene promoters, transfections were performed in SK-BR-3 cells using reporter constructs containing the lymphoid/decidual promoter (1a1878PRL-Luc) or successive 5'-deletions of the pituitary hPRL control region: 3474P-Luc, 1750P-Luc, 740P-Luc, 250P-Luc, 164PLuc and 40P-Luc (Fig. 2A). Significant basal transcriptional activity was observed in SK-BR-3 with all promoter constructs when compared with the minimal promoter construct 40P-Luc in this transient assay (Fig. 2B). Successive 5'-deletions of the pituitary hPRL promoter resulted in a gradual decrease of reporter gene expression, demonstrating the presence of cis elements necessary for full activity along the entire upstream regulatory region.

In pituitary cells, the cell-specific transcription factor Pit-1 is one of the main activators of the hPRL gene pituitary promoter. To assess the presence of Pit-1 in SK-BR-3 cells, we performed RT-PCR experiments on mRNA from these cells using primers specific for human Pit-1. A specific fragment corresponding to a normally spliced Pit-1 cDNA was only observed in pituitary GX cells, used as a positive control, whereas no signal was obtained in HeLa and SK-BR-3 cells (Fig. 2C). When SKBR-3 cells were cotransfected with the 3474P-Luc construct and an expression vector for human Pit-1, a strong activation was observed as compared to the control with an empty expression vector (Fig. 2D).

The effect of hPit-1 expression on the endogenous hPRL gene was also examined (Fig. 2E). Immunostaining of hPRL is significantly stronger in Pit-1 transfected SK-BR-3 cells as compared to mock-transfected cells, showing for the first time that the endogenous hPRL gene is able to respond to Pit-1 in nonpituitary human cells. 
These results not only show that Pit-1 is able to activate both transfected hPRL pituitary promoter and endogenous $h P R L$ in mammary SK-BR-3 cells, but also that a significant activity of this promoter is observed in the absence of the pituitary factor Pit-1. The transfected lymphoid/decidual promoter displays a similar basal activity.

EGF activates the hPRL pituitary promoter in SK-BR-3 cells

SK-BR-3 cells are known to highly express some members of the EGF/Neu receptor family (EGFR/ErbB1, ErbB2, ErbB3 and ErbB4), especially erbB1 and 2. Therefore, we tested the hPRL promoters for their ability to respond to EGF in these cells. Used as a negative control, the 40P-Luc construct containing only a TATAbox displayed a weak (2-fold) stimulation, probably reflecting a non-specific activation of the basal transcription machinery by EGF (Fig. 3A). Compared to 40P-Luc, the 3474P-Luc pituitary promoter construct was significantly stimulated by EGF treatment. In contrast, the lymphoid/decidual promoter (1a1878PRL-Luc) did not respond to EGF, suggesting that EGF signaling selectively targets the pituitary promoter. When the 5'-deleted pituitary promoter constructs were tested, EGF stimulation was clearly maintained, even with the shortest 164P-Luc construct, suggesting that EGF stimulation in SK-BR-3 cells acts on the 164 most proximal base pairs of the hPRL pituitary promoter.

\footnotetext{
The endogenous pituitary-type hPRL mRNA is up-regulated by EGF in SK-BR-3 cells

EGF regulation of the endogenous hPRL gene in SK-BR-3 cells was monitored by semi-quantitative RT-PCR. After 25 amplification cycles (in the linear part of the PCR reaction), the signal obtained from EGF-treated SK-BR-3 was clearly stronger than from control cells (Fig. 3B, left panel). Thus, the amount of hPRL mRNA was significantly increased in SK-BR-3 cells upon EGF
} 
treatment as compared with control cells. In contrast, the constitutive $\alpha$-tubulin transcription was not affected.

When PCR reactions were performed using the forward primers forla or forlb and the reverse primer rev2, an enhanced signal (at least 2-3 fold) upon EGF treatment was only observed with for $1 b$, corresponding to pituitary-type hPRL mRNA.

\section{EGF induces the binding of an AP-1 complex within the proximal hPRL promoter}

Deletion analysis of the hPRL promoter revealed that the EGF activated pathway targets mainly the $-164 /+1$ most proximal regulatory region. This region contains two Pit-1 binding sites, the "sequence $A$ " binding ubiquitous factors and an AP-1 binding element located upstream from the proximal Pit-1 binding site in the $\mathrm{P} 1$ region (Fig. 4A). This AP-1 site is critical for basal and okadaic acid (a protein phosphatase inhibitor) regulated transcription in pituitary GH3B6 cells (Caccavelli et al., 1998; Manfroid et al., 2001). We assessed the role of AP-1, a potential EGF target, in the EGF-induction of the hPRL promoter in SK-BR-3 cells. Mutation of the AP-1 binding site in 164P-Luc clearly decreased EGF-stimulation of the $164 \mathrm{hPRL}$ promoter in SK-BR-3, close to that of the minimal 40P-Luc construct (Fig. 4B). Mutation of the proximal Pit-1 binding site in 164P-Luc resulted in a two-fold decrease of the basal level, but the EGF stimulation was hardly affected (Fig. 4B and 4C).

Gel retardation assays were performed to compare DNA binding factors in SK-BR-3 cells in absence or presence of EGF. The binding properties of sequence $A$ or $P 2$ were not influenced upon EGF treatment, consistent with a role in the EGF response for $\mathrm{P} 1$ alone (Fig. 5A, lanes 15 and 18). Using a probe encompassing the $\mathrm{P} 1$ region (containing the $\mathrm{AP}-1$ site and the proximal Pit-1 site), a strongly enhanced complex was observed upon EGF treatment (lane 3). An additional, more slowly migrating complex was also observed, which was not consistently induced by EGF (compare lane 
3 and 21, and see below). The faster migrating complex was not obtained when the P1 sequence mutated in the AP-1 site was used (lane 12). In contrast, mutation of the Pit-1 binding site did not affect formation of this complex (lane 9). A similar complex was observed on a consensus AP-1 response element in $\mathrm{SK}-\mathrm{BR}-3$ cells treated with EGF (lane 6). Competition experiments (Fig. 5B) revealed that an excess of cold P1 oligonucleotide, P1 mutated in the Pit-1 site or a consensus AP-1 site abolished formation of this complex, while the P1 probe mutated in the AP-1 site, a consensus Oct-1 site or the unrelated NF-Y binding site had no effect. Taken together, these results strongly suggest that EGF induces the binding of an AP-1 complex to P1. Using specific antibodies, we show that this complex is composed of the proto-oncogenes c-fos and c-jun, as demonstrated by the supershift and the abrogation of the shift induced, respectively by c-fos and c-jun antibodies (lanes 12, 14). The other fos and jun family members FosB, JunB and JunD were not detected in the AP-1 complex (lanes 13, 15, 16). The slower complex observed on P1 was also observed with the P2 probe, containing a Pit-1 binding site. Mutation of the Pit-1 site abolished the formation of this complex and competition with an excess of cold P2 or a consensus site for Oct-1 allowed us to identify this complex as Oct-1 (lane 8). The supershift observed with specific Oct-1 antibodies confirmed this conclusion (lane 10).

Western blot analysis of nuclear proteins in SK-BR-3 revealed that the c-fos and c-jun protein levels dramatically increase upon EGF treatment, probably accounting for the increased binding of these factors to AP-1 elements (Fig. 5C). Moreover, EGF treatment did not affect the other AP-1 proteins JunB, JunD, FosB and Fra-1, consistent with the results obtained in gel retardation experiments. Fra-2 could not be detected (not shown).

EGF stimulation of hPRL involves activation of JNK by PI3K 
Activation of the EGF receptor triggers several different signal transduction pathways, depending on the cell type and the precise physiological condition of the cells. To gain some insight into the mechanism of hPRL stimulation by EGF, specific inhibitors were used.

SK-BR-3 cells were transfected with the 3474-PRL pituitary promoter construct and its activation by EGF was determined. As expected, the three-fold stimulation of hPRL promoter activity was completely abolished when the specific inhibitor (AG1478) of the EGF receptor was added (Fig. 6). Inhibition of ras (AFC) or the protein kinases MEK1/2 (PD98059), p38 (SB203580) and protein kinase $C$ (Bis) only marginally affected the hPRL promoter activity in the presence of EGF. In contrast, inhibition of the PI3-Kinase resulted in a significant decrease of EGF-stimulated hPRL activity. None of these drugs significantly affected the hPRL basal level transcription. Thus, PI3K is clearly involved in EGF-stimulation of the hPRL pituitary promoter in SK-BR-3 cells.

A possible target for the PI3K pathway is the c-Jun NH2terminal kinase, which is also the main kinase known to control c-jun and AP-1 activity (Hibi et al., 1993). To test whether JNK is involved in hPRL activation, we performed immunofluorescence staining using an anti-phospho-JNK antibody (Fig. 7). A strong staining was obtained with EGF-treated cells, similar to that in UV-treated cells that were used as positive control, suggesting that EGF is able to stimulate JNK in SK-BR-3. More importantly, addition of the PI3K inhibitor Wortmannin to the EGF-treated cells reduced phospho-JNK staining to the level obtained with Wortmannin alone, or in untreated control cells. These results indicate that JNK is likely involved in EGF and PI3K activation of hPRL gene expression mediated by AP-1.

\section{DISCUSSION}


The previously described expression of hPRL in several mammary cell lines (Fields et al., 1993; Clevenger et al., 1995; Ginsburg and Vonderhaar, 1995; Shaw-Bruha et al., 1997) is particularly interesting, as this tissue also is the major target site for PRL in mammals. Here, we describe for the first time the molecular mechanisms involved in transcription of the hPRL gene in SK-BR-3 mammary tumor cells and we show that EGF and hPit-1 stimulate transcription of both the endogenous hPRL gene and a transfected hPRL promoter.

The pituitary promoter drives hPRL expression in SK-BR-3 cells

Two alternative transcriptional start sites were described for the hPRL gene. One is used in the pituitary (exon1b); the other in various extra-pituitary expression sites that produce a mRNA extended in its 5'-untranslated region (exonla). Using RT-PCR, the presence of hPRL mRNA containing exonla was observed in normal as well as neoplastic human mammary tissues and in tumor cell lines, while mRNA containing only exon1b was detected in other cells (Shaw-Bruha et al., 1997). Here, we confirm the synthesis of hPRL both at the protein and the mRNA level in SKBR-3 cells, a highly tumorigenic cell line. The presence of exonla was not detected in SK-BR-3 mRNA by RT-PCR, indicating that the hPRL mRNA is not of the lymphoid/decidual type and thus that a different promoter is used in these cells. Transient expression experiments showed that the pituitary promoter is indeed functional in SK-BR-3 cells and drives significant expression of the luciferase reporter gene as compared to the 40P-Luc construct containing only the TATA-box. The expression pattern observed for the 5'-deletion constructs is similar to that obtained in pituitary cells (Van de Weerdt et al., 2000). The observed basal activity of the decidual/lymphoid promoter was previously shown in a number of different cell lines (Gaasenbeek et al., 1999). One of the main activators of the pituitary promoter is the transcription factor Pit-1. No mRNA coding for 
human (h)Pit-1 was detected by RT-PCR in SK-BR-3 cells, however the transfected pituitary promoter is clearly induced by expression of hPit-1, while the transfected lymphoid/decidual promoter is not (Gellersen et al., 1994 and Fig. 3). EGF treatment also induces specifically the transfected pituitary promoter. Interestingly, expression of hPit-1 and treatment with EGF also clearly enhance expression of the endogenous hPRL gene. The fact that the transfected and the endogenous hPRL pituitary promoters are both induced by EGF and hPit-1 argues for the use of the hPRL pituitary promoter in SK-BR-3 cells. Although we cannot exclude the presence of a third, not yet identified, promoter in the hPRL gene as we have not formally determined the transcription start site, our results strongly indicate that the hPRL pituitary promoter is used in SK-BR-3 cells. In addition, these cells are the first non-pituitary human cells where Pit-1 and EGF stimulation of the endogenous hPRL gene was observed.

HPRL promoter activity in SK-BR-3 cells does not require Pit1, possibly replaced by the POU-domain factor Oct-1.

Previously, pituitary-type transcription of the hPRL gene (originating at exon $1 \mathrm{~b}$ ) was observed in the uterine cell line SK-UT-1B-20 (Gellersen et al., 1995). However, similar to hPRL expression in lymphocytes, (Gellersen et al., 1994), the expression was mainly controlled by a region located in the decidual/lymphoid promoter, and significant activity of the transfected pituitary proximal promoter was only observed when exogenous Pit-1 was expressed (Gellersen et al., 1994; 1995). In contrast, in SK-BR-3 cells, an expression pattern of the 5'deletion constructs similar to that observed in pituitary cells was obtained in the absence of hPit-1. A 7-fold higher activity relative to $40 \mathrm{P}-\mathrm{Luc}$ is obtained even with the shortest promoter construct tested, the 164P-Luc. Addition of further upstream sequences resulted in a gradual increase of transcriptional activity, suggesting that multiple activating sites are present 
in this region. Pit-1 binding sites are obvious candidates for such a regulation. Mutation of only the most proximal Pit-1 site results in a clear decrease of expression from the 164P-Luc construct. We show in gel retardation experiments that this site is able to bind in vitro the ubiquitous oct-1, a member of the POU homeobox protein family also containing Pit-1. Binding to the P1 site by Oct-1 was also previously shown in pituitary cells (Caccavelli et al., 1998) and synergistic activation by Oct-1 and Pit-1 of the rat PRL promoter was reported (Voss et al., 1991). Thus, it is likely that Oct-1 substitutes for Pit-1 in basal expression of the hPRL promoter in SK-BR-3 cells. Mutation of the adjacent AP-1 site also decreased basal expression suggesting that AP-1 contributes to promoter activity, similar to what was shown before in rat pituitary cells (Caccavelli et al., 1998; Manfroid et al., 2001).

EGF stimulates the hPRL pituitary promoter through the

\section{PI3K/JNK/AP-1 pathway}

EGF is an important regulator of mammary gland development as well as breast tumor growth (Kim and Muller, 1999). In SK-BR-3 cells, EGF stimulation of 164P-Luc involves the AP-1 site adjacent to the most proximal Pit-1 binding sequence. Although both sites contribute to the basal hPRL promoter activity (see above), the Pit (Oct)-1 site is not required for EGF regulation.

We previously showed that the enhanced binding of AP-1 complexes in pituitary cells upon stimulation of the MEK/ERK pathway results from an increase in cellular amounts of c-fos and jund (Caccavelli et al., 1998; Manfroid et al., 2001). In SK-BR-3 cells, the amount of AP-1 complexes is also increased upon EGF treatment, but the complex formed is a c-fos/c-jun dimer. EGF binding to its tyrosine kinase receptor EGFR (ErbB1) leads to receptor heterodimerization with ErbB2, phosphorylation of both receptors and activation of downstream pathways such as Ras/Raf/MEKs/ERKs, Ras/MEKKs/MKKs/JNK, PI3K/AKT or p70S6K (Kim 
and Muller, 1999). To understand the molecular events leading to the hPRL promoter stimulation by EGF, we used specific kinase inhibitors. Other than blocking the EGFR itself, only inhibition of PI3K led to a decrease of EGF stimulation of the hPRL pituitary promoter. We further show that EGF activates JNK in a PI3K-dependent way. Thus, our results suggest that EGF stimulation of the hPRL gene in SK-BR-3 cells involves the EGFR/PI3K/JNK/AP-1 pathway.

PRL expression has been observed in normal and tumoral breast tissues as well as in mammary cell lines (Fields et al., 1993; Clevenger et al., 1995; Ginsburg and Vonderhaar, 1995; Shaw-Bruha et al., 1997). In humans, a role in cancer initiation and progression has been proposed (reviewed in clevenger et al., 2003 ). PRL stimulates human breast cancer cell proliferation (Fuh and Wells, 1995; Llovera et al., 2000; Acosta et al., 2003; Schroeder et al., 2003), particularly PRL stimulates SK-BR-3 cell growth, whereas PRL antagonists block their proliferation (Fuh and Wells, 1995). The existence of an autocrine/paracrine mitogenic loop following local synthesis of PRL in mammary tissue itself was proposed (reviewed in Ben-Jonathan et al., 2002). As observed in 25-50\% of human breast cancers (Slamon et al., 1987; Bacus et al., 1994), SK-BR-3 cells express high levels of EGFR (ErbB1) and of constitutively activated ErbB2. Recently, Yamauchi et al. (Yamauchi et al., 2000) demonstrated that PRL secreted by SK-BR-3 cells is able to activate ErbB2 and the MAPK pathway via autocrine binding to PRLR followed by Jak2 activation. The stimulation of hPRL synthesis by EGFR/ErbB2 with the subsequent activation of $\mathrm{PI} 3 \mathrm{~K} / \mathrm{JNK} / \mathrm{AP}-1$ offers a potential mechanism for autostimulation of mammary tumor cells such as SK-BR-3.

Taken together, our results provide first insights into the control of local expression of hPRL in mammary cells and contribute to the understanding of the regulatory network underlying hPRL expression in extra-pituitary cells. 


\section{Acknowledgements}

The authors are grateful to P. Herrlich and A. Chariot for kindly providing the pRSV-JunD and pRSV-c-fos and the pcDNA3hPit1, respectively. This work was supported by grants from the "Région Wallone (ULg 1815); the "Services Fédéraux des Affaires Scientifiques, Techniques et Culturelles" (PAI P3-042, P3-044 and P4/30 and "Actions de Recherche Concertees": 95/00-193); the Fonds National de la Recherche Scientifique (FNRS) (-3.4537.93 and -9.4569.95). I. Manfroid held a doctoral fellowship from the F.R.I.A and from the patrimoine ULg. M. M. is a "Chercheur qualifié" at the Fonds National de la Recherche Scientifique (FNRS). This work contains part of the Ph.D. thesis of I. Manfroid. 


\section{REFERENCES}

Acosta., J.J., Munoz, R.M., Gonzalez, L., Subtil-Rodriguez, A., Dominguez-Caceres, M.A., Garcia-Martinez, J.M., Calcabrini, A., Lazaro-Trueba, I., Martin-Perez, J., 2003. Src mediates prolactin-dependent proliferation of T47D and MCF7 cells via the activation of focal adhesion kinase/Erk1/2 and phosphatidylinositol 3-kinase pathways. Mol. Endocrinol. 17, 2268-2282.

Anderson, E., Ferguson, J.E., Morten, H., Shalet, S.M., Robinson, E.L., Howell, A., 1993. Serum immunoreactive and bioactive lactogenic hormones in advanced breast cancer patients treated with bromocriptine and octreotide. Eur. J. Cancer. 29, 209-217. Bacus, S.S., Zelnick, C.R., Plowman, G., Yarden, Y., 1994. Expression of the erbB-2 family of growth factor receptors and their ligands in breast cancers. Implication for tumor biology and clinical behavior. Am. J. Clin. Pathol. 102, 13-24.

Ben-Jonathan, N., Liby, K., McFarland, M., Zinger, M., 2002 . Prolactin as an autocrine/paracrine growth factor in human cancer. Trends Endocrinol. Metab. 13, 245-250.

Berwaer, M., Martial, J.A., Davis, J.R., 1994. Characterization of an up-stream promoter directing extrapituitary expression of the human prolactin gene. Mol. Endocrinol. 8, 635-642.

Berwaer, M., Peers, B., Nalda, A.M., Monget, P., Davis, J.R., Belayew, A., Martial, J.A., 1993. Thyrotropin-releasing hormone and epidermal growth factor induce human prolactin expression via identical multiple cis elements. Mol. Cell. Endocrinol. 92, 1-7.

Berwaer, Mi, Monget, $\mathrm{P}$; , Peers, P., Mathy-Hartert, M., Bellefroid, E., Davis, J.R., Belayew, A., Martial, J.A., 1991. Multihormonal regulation of the human prolactin gene expression 
from 5000 bp of its upstream sequence. Mol. Cell. Endocrinol. 80, 53-64.

Bhatavdekar, J.M., Shah, N.G., Balar, D.B., Patel, D.D., Bhaduri, A., Trivedi, S.N., Karelia, N.H., Ghosh, N., Shukla, M.K., Giri, D.D., 1990. Plasma prolactin as an indicator of disease progression in advanced breast cancer. Cancer 65, 2028-2032.

Biswas, R., Vonderhaar, B.K., 1987. Role of serum in the prolactin responsiveness of $\mathrm{MCF}-7$ human breast cancer cells in long-term tissue culture. Cancer Res. 47, 3509-3514.

Brar, A.K., Kessler, C.A., Handwerger, S., 2002. An Ets motif in the proximal decidual prolactin promoter is essential for basal gene expression. J. Mol. Endocrinol. 29, 99-112.

Caccavelli, L., Manfroid, I., Martial, J.A., Muller, M., 1998. Transcription factor AP1 is involved in basal and okadaic acidstimulated activity of the human PRL promoter. Mol. Endocrinol. $12,1215-1227$.

Chen, N.Y., Holle, L., Li, W., Peirce, S.K., Beck, M.T., Chen, W.Y., 2002. In vivo studies of the anti-tumor effects of a human prolactin antagonist, hPRL-G129R. Int. J. Oncol. 20, 813-818.

Chomczynski, P., Soszynski, P.A., Frohman, L.A., 1993. Stimulatory effect of thyroid hormone on growth hormone gene expression in a human pituitary cell line. J. Clin. Endocrinol. Metab. 77, 281-285.

Clevenger, C.V., Chang, W.P., Ngo, W., Pasha, T.L., Montone, K.T., Tomaszewski, J.E., 1995. Expression of prolactin and prolactin receptor in human breast carcinoma. Evidence for anautocrine/paracrine loop. Am. J. Pathol. 146, 695-705.

Clevenger, C.V., Furth, P.A., Hankinson, S.E., Schuler, L.A., 2003. The role of prolactin in mammary carcinoma. Endocr. Rev. $24,1-27$. 
DiMattia, G.E., Gellersen, B., Bohnet, H.G., Friesen, H.G., 1988 . A human B-lymphoblastoid cell line produces prolactin. Endocrinology 122, 2508-2517.

DiMattia, G.E., Gellersen, B., Duckworth, M.L., Friesen, H.G., 1990. Human prolactin gene expression. The use of an alternative noncoding exon in decidua and the IM-9-P3 lymphoblast cell line. J. Biol. Chem. 265, 16412-16421.

Fields, K., Kulig, E., Lloyd, R.V., 1993. Detection of prolactin messenger RNA in mammary and other normal and neoplastic tissues by polymerase chain reaction. Lab. Invest. 68, 354-360.

Fuh, G., Wells, J.A., 1995. Prolactin receptor antagonists that inhibit the growth of breast cancer cell lines. J. Biol. Chem. 270 , 13133-13137.

Gaasenbeek, M., Gellersen, B., DiMattia, G.E., 1999 DNase I hypersensitivity analysis of non-pituitary human prolactin gene expression. Mol Cell Endocrinol. 152:147-159.

Gellersen, B., DiMattia, G.E., Friesen, H.G., Bohnet, H.G., 1989. Prolactin (PRL) mRNA from human decidua differs from pituitary PRL mRNA but resembles the IM-9-P3 lymphoblast PRL transcript. Mol. Cell. Endocrinol. 64, 127-130.

Gellersen, B., Kempf, R., Telgmann, R., DiMattia, G.E., 1994. Nonpituitary human prolactin gene transcription is independent of Pit-1 and differentially controlled in lymphocytes and in endometrial stroma. Mol. Endocrinol. 8, 356-373.

Gellersen, B., Kempf, R., Telgmann, R., DiMattia, G.E., 1995. Pituitary-type transcription of the human prolactin gene in the absence of Pit-1. Mol. Endocrinol. 9, 887-901.

Gerlo, S., Vanden Berghe, W., Verdood, P., Hooghe-Peters, E.L., Kooijman, R., 2003. Regulation of prolactin expression in leukemic cell lines and peripheral blood mononuclear cells. J. Neuroimmunol. 135, 107-116. 
Ginsburg, E., Vonderhaar, B.K., 1995. Prolactin synthesis and secretion by human breast cancer cells. Cancer Res. 55, 25912595 .

Hankinson, S.E., Willett, W.C., Michaud, D.S., Manson, J.E., Colditz, G.A., Longcope, C., Rosner, B., Speizer, F.E., 1999. Plasma prolactin levels and subsequent risk of breast cancer in postmenopausal women. J. Natl. Cancer Inst. 91, 629-634.

Hibi, M., Lin, A., Smeal, T., Minden, A., Karin, M., 1993. Identification of an oncoprotein- and UV-responsive protein kinase that binds and potentiates the c-Jun activation domain. Genes Dev. 7, 2135-2148.

Hoggard, N., Davis, J.R., Berwaer, M., Monget, P., Peers, B., Belayew, A., Martial, J.A., 1991. Pit-1 binding sequences permit calcium regulation of human prolactin gene expression. Mol. Endocrinol. 5, 1748-1754.

Holtkamp, W., Nagel, G.A., Wander, H.E., Rauschecker, H.F., von Heyden, D., 1984. Hyperprolactinemia is an indicator of progressive disease and poor prognosis in advanced breast cancer. Int. J. Cancer 34, 323-328.

Kim, H., Muller, W.J., 1999. The role of the epidermal growth factor receptor family in mammary tumorigenesis and metastasis. Exp. Cell Res. 253, 78-87.

Lai, J.S., Herr, W., 1992. Ethidium bromide provides a simple tool for identifying genuine DNA-independent protein associations. Proc. Natl. Acad. Sci. U. S. A. 89, 6958-6962. Le Provost, F., Leroux, C., Martin, P., Gaye, P., Djiane, J., 1994. Prolactin gene expression in ovine and caprine mammary gland. Neuroendocrinology 60, 305-313.

Llovera, M., Pichard, C., Bernichtein, S., Jeay, S., Touraine, P., Kelly, P.A., Goffin, V., 2000. Human prolactin (hPRL) 
antagonists inhibit hPRL-activated signaling pathways involved in breast cancer cell proliferation. Oncogene 19, 4695-4705. Llovera, M., Touraine, P., Kelly, P.A., Goffin, V., 2000. Involvement of prolactin in breast cancer: redefining the molecular targets. Exp. Gerontol. 35, 41.

Manfroid, I., Martial, J.A., Muller, M., 2001. Inhibition of protein phosphatase PP1 in GH3B6, but not in GH3 cells, activates the MEK/ERK/C-fos pathway and the human prolactin promoter, involving the coactivator CPB/p300. Mol. Endocrinol. 15, 625-637. Muller, M., Berwaer, M., Caccavelli, L., Manfroid, I., Nalda, A., Pendeville, H., Pernasetti, F., Van de Weerdt, C., Peers, B., Martial, J.A., 1998. Transcriptional regulation of the prolactin gene. Médecine/Sciences 14, 580-587.

Nalda, A.M., Martial, J.A., Muller, M., 1997. The glucocorticoid receptor inhibits the human prolactin gene expression by interference with Pit-1 activity. Mol. Cell. Endocrinol. 134, 129-137.

Paris, N., Rentier-Delrue, F., Defontaine, A., Goffin, V., Lebrun, J.J., Mercier, L., Martial, J.A., 1990. Bacterial production and purification of recombinant human prolactin. Biotechnol. Appl. Biochem. 12, 436-449.

Peers, B., Monget, P., Nalda, M.A., Voz, M.L., Berwaer, M., Belayew, A., Martial, J.A., 1991. Transcriptional induction of the human prolactin gene by cAMP requires two cis-acting elements and at least the pituitary-specific factor Pit-1. J. Biol. Chem. 266, 18127-18134.

Peers, B., Voz, M.L., Monget, P., Mathy-Hartert, M., Berwaer, M., Belayew, A., Martial, J.A., 1990. Regulatory elements controlling pituitary-specific expression of the human prolactin gene. Mol Cell. Biol. 10, 4690-4700. 
Pellegrini, I., Lebrun, J.J., Ali, S., Kelly, P.A., 1992. Expression of prolactin and its receptor in human lymphoid cells. Mol. Endocrinol. 6, 1023-1031.

Pernasetti, F., Caccavelli, L., Van de Weerdt, C., Martial, J.A., Muller, M., 1997. Thyroid hormone inhibits the human prolactin gene promoter by interfering with activating protein-1 and estrogen stimulations. Mol. Endocrinol. 11, 986-996.

Pohnke, Y., Kempf, R., Gellersen, B., 1999. CCAAT/enhancerbinding proteins are mediators in the protein kinase A-dependent activation of the decidual prolactin promoter. J. Biol. Chem. $274,24808-24818$.

Poncelet, A.C., Levavi-Sivan, B., Muller, M., Yaron, Z., Martial, J.A., Belayew, A., 1996. The tilapia prolactin I gene: evolutionary conservation of the regulatory elements directing pituitary-specific expression. DNA Cell. Biol. 15, 679-692.

Reem, G.H., Ray, D.W., Davis, J.R., 1999. The human prolactin gene upstream promoter is regulated in lymphoid cells by activators of T-cells and by CAMP. J. Mol. Endocrinol. 22, 285292 .

Reynolds, C., Montone, K.T., Powell, C.M., Tomaszewski, J.E., Clevenger, C.V., 1997. Expression of prolactin and its receptor in human breast carcinoma. Endocrinology 138, 5555-5560.

Schroeder, M.D., Brockman, J.L., Walker, A.M., Schuler, L.A., 2003 Inhibition of prolactin (PRL)-induced proliferative signals in breast cancer cells by a molecular mimic of phosphorylated PRL, S179D-PRL. Endocrinology • 144, 5300-5307.

Shaw-Bruha, C.M., Pirrucello, S.J., Shull, J.D., 1997. Expression of the prolactin gene in normal and neoplastic human breast tissues and human mammary cell lines: promoter usage and alternative mRNA splicing. Breast Cancer Res. Treat. 44, 243-253. 
Shiu, R.P., Murphy, L.C., Tsuyuki, D., Myal, Y., Lee-Wing, M., Iwasiow, B., 1987. Biological actions of prolactin in human breast cancer. Recent Prog. Horm. Res. 43, 277-303.

Slamon, D.J., Clark, G.M., Wong, S.G., Levin, W.J., Ullrich, A., McGuire, W.L., 1987. Human breast cancer: correlation of relapse and survival with amplification of the HER-2/neu oncogene. Science 235, 177-182.

Struman, I., Bentzien, F., Lee, H., Mainfroid, V., D'Angelo, G., Goffin, V., Weiner, R.I., Martial, J.A., 1999. Opposing actions of intact and N-terminal fragments of the human prolactin/growth hormone family members on angiogenesis: an efficient mechanism for the regulation of angiogenesis. Proc. Natl. Acad. Sci. U. S. A. $96: 1246-1251$.

Telgmann, R., Maronde, E., Tasken, K., Gellersen, B., 1997. Activated protein kinase $A$ is required for differentiationdependent transcription of the decidual prolactin gene in human endometrial stromal cells. Endocrinology 138, 929-937.

Truong, A.T., Duez, C., Belayew, A., Renard, A., Pictet, R., Bell, G.I., Martial, J.A., 1984. Isolation and characterization of the human prolactin gene. EMBO J. 3, 429-437.

Van De Weerdt, C., Peers, B., Belayew, A., Martial, J.A., Muller, M., 2000. Far Upstream Sequences Regulate the Human Prolactin Promoter Transcription. Neuroendocrinology 71, 124-137.

Voss, J.W., Wilson, L., Rosenfeld, M.G., 1991 POU-domain proteins Pit-1 and Oct-1 interact to form a heteromeric complex and can cooperate to induce expression of the prolactin promoter. Genes Dev $5: 1309-1320$

Yamauchi, T., Yamauchi, N., Ueki, K., Sugiyama, T., Waki, H., Miki, H., Tobe, K., Matsuda, S., Tsushima, T., Yamamoto, T., Fujita, T., Taketani, Y., Fukayama, M., Kimura, S., Yazaki, Y., Nagai, R., Kadowaki, T., 2000. Constitutive tyrosine 
phosphorylation of ErbB-2 via Jak2 by autocrine secretion of prolactin in human breast cancer. J. Biol. Chem. 275, 3393733944 . 


\section{FIGURE LEGENDS :}

FIG. 1. HPRL is expressed in SK-BR-3 cells from a mRNA containing exon 1b, but not the lymphoid/decidual specific exon 1a. A. Western blot showing expression of hPRL protein in whole cell extracts $(60 \mu \mathrm{g})$ from human mammary SK-BR-3 cells. Equal amounts of extracts from HeLa and Jurkat cells were used as negative and positive control, respectively. For comparison, the indicated amounts of bacterially expressed and purified hPRL were also loaded. B. Schematic representation of the pituitary-type and the lymphoid/decidual-type hPRL mRNA and localization of the primers used in the RT-PCR experiments. C. RT-PCR performed with the primers designed in exon 3,4 and 5 of the hPRL gene. Primers inside the $\alpha$-tubuline gene were used to control the PCR reactions. HeLa cells are the negative control and Jurkat and GX were used as a positive control. D. Determination of the exons ( $1 \mathrm{a}$ or 1b) present in the hPRL mRNA in SK-BR-3 cells. Jurkat and GX mRNAs were used as controls for exonla and $1 \mathrm{~b}$ respectively.

FIG. 2. Transcription of the hPRL gene in SK-BR-3 cells is driven by the pituitary promoter in the absence of the pituitary factor Pit-1. A. Illustration of the pituitary and the upstream lymphoid/decidual promoters. The promoter constructs used in transfection experiments are indicated. B. Promoter activity measured in transient expression experiments performed with the pituitary and decidual/lymphoid promoter constructs. The activities of the 5'-deletion constructs of the pituitary promoter are included. The minimal construct 40P-Luc contains only the TATA box of the pituitary promoter. Activities are normalized to the protein concentration of the extracts and shown as the mean relative light units \pm S.D. from triplicate 
experiments performed at least twice C. RT-PCR reactions performed with primers within the hPit-1 gene. Pituitary GX cells were used as positive control. D. Transient expression experiments showing the pituitary promoter activity in absence and presence of transfected hPit-1 expression vector in SK-BR-3 cells. E. Immunostaining with anti-hPRL antibody on SK-BR-3 cells transfected with hPit-1 expression vector or mock-transfected control. The cells were observed at a 100- (left) or 300-fold (right) magnification.

FIG. 3. In SK-BR-3 cells, EGF stimulates both the transfected and the endogenous hPRL pituitary promoter. A. SK-BR-3 cells were transfected with the indicated hPRL lymphoid/decidual or pituitary promoter constructs and treated or not with $50 \mathrm{ng} / \mathrm{ml}$ of EGF. The results are shown as fold induction by EGF relative to untreated cells \pm S.D. from triplicate experiments performed at least twice is shown. B. RT-PCR reactions were performed on mRNA from control and EGF-treated SK-BR-3 cells. Calibration was performed by amplifying the $\alpha$-tubulin gene (left panel). Exonlaor exon1b-specific reactions are also shown (right panel). Refer to Fig. 1B for the nomenclature and positions of the primers used in the PCR reactions.

FIG. 4. Mutation of the AP-1 binding site in the proximal hPRL pituitary promoter abolishes EGF stimulation, while AP-1 and Pit1 sites both govern basal transcription. A. Detailed representation of the 164P-Luc construct containing the proximal pituitary promoter of the hPRL gene. Regions corresponding to binding sites $\mathrm{P} 2, \mathrm{~A}$ and $\mathrm{P} 1$ are shown as well as the specific AP-1 and Pit-1 recognition sites. B. The $164 \mathrm{P}-\mathrm{Luc}$ construct and its mutant versions in the AP-1 or Pit-1 site were transfected into 
SK-BR-3 cells and the transcriptional activity in the presence of $50 \mathrm{ng} / \mathrm{ml}$ was determined relative to untreated controls. C. The basal activity in the absence of EGF is shown for each of the constructs.

FIG. 5. EGF induces the binding of a c-jun/c-fos complex to the AP-1 binding site of the pituitary proximal hPRL promoter. A. Gel retardation experiments performed with nuclear protein from untreated control and EGF-treated SK-BR-3 extracts. The cells were treated the day after seeding with $50 \mathrm{ng} / \mathrm{ml} \mathrm{EGF}$ for $18 \mathrm{~h}$. Probes corresponding to the $\mathrm{P} 1$, a consensus AP-1, P1(Pitm), $\mathrm{P} 1(\mathrm{AP} 1 \mathrm{~m})$, sequence " $\mathrm{A}$ " and $\mathrm{P} 2$ were used, as indicated. The probes were incubated alone or in the presence of untreated and treated cell extract. The position of the AP-1 complex is indicated. The slower migrating complex (arrow) is not detected upon EGF treatment in a separate independent experiment (probe P1, right panel). B. (Left panel) Competition experiments using the P1 probe with nuclear extracts from EGF-treated SK-BR-3 cells and a 200-fold excess of the indicated cold oligonucleotides. (Right panel) Identification of the EGF-induced complex using specific antibodies as indicated. The c-fos antibody induces a supershift, while anti-c-jun prevents complex formation $\mathrm{C}$. Analysis of the protein amounts of different members of the AP-1 protein family in nuclear extracts from SK-BR-3 cells treated with EGF as compared to control cells.

FIG. 6. EGF activation of the hPRL pituitary promoter involves the PI3K. SK-BR-3 cells were transfected with 3474P-Luc and treated or not with EGF. In addition, solvent or inhibitors of

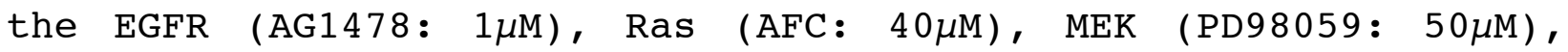

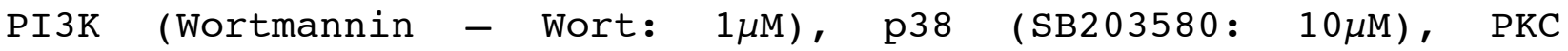


(bisindolylmaleimide - bis: $2.5 \mu \mathrm{M}$ ) protein kinases were added and fold induction relative to untreated cells is shown from triplicate experiments performed at least twice. The unshaded bar on the left represents control cells not treated with EGF or any of the inhibitors (fold-induction equal to $1 \pm$ S.D.)

FIG. 7. EGF stimulates JNK phosphorylation by PI3K. SK-BR-3 cells treated as indicated were immunostained with anti-phospho-JNK antibodies. UV-irradiation was used as positive control for JNK phosphorylation. 
A

\begin{tabular}{|c|c|c|c|}
\hline hPRL protein & \multicolumn{3}{|c|}{ Total cell extracts } \\
\hline$\underline{\mathrm{ng}}$ & $\begin{array}{l}9 \\
1 \\
q\end{array}$ & + & \\
\hline $200 \quad 500$ & $\frac{\dot{u}}{\omega}$ & 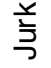 & $\frac{1}{1}$ \\
\hline & & $=$ & \\
\hline
\end{tabular}

B

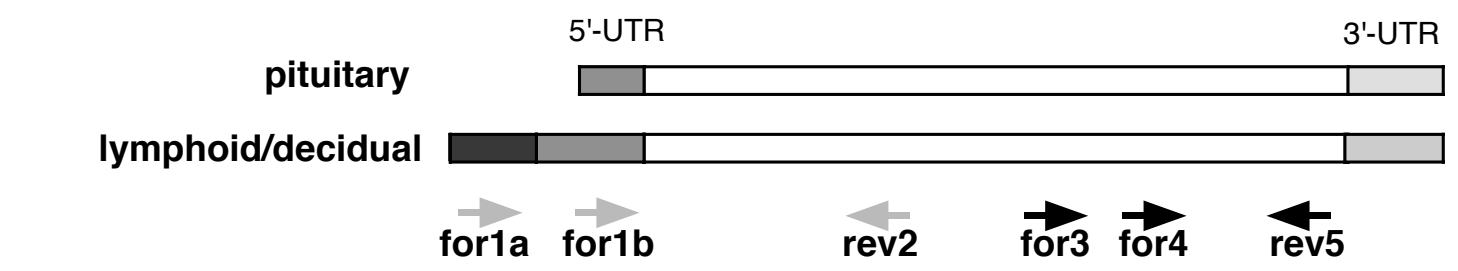

C

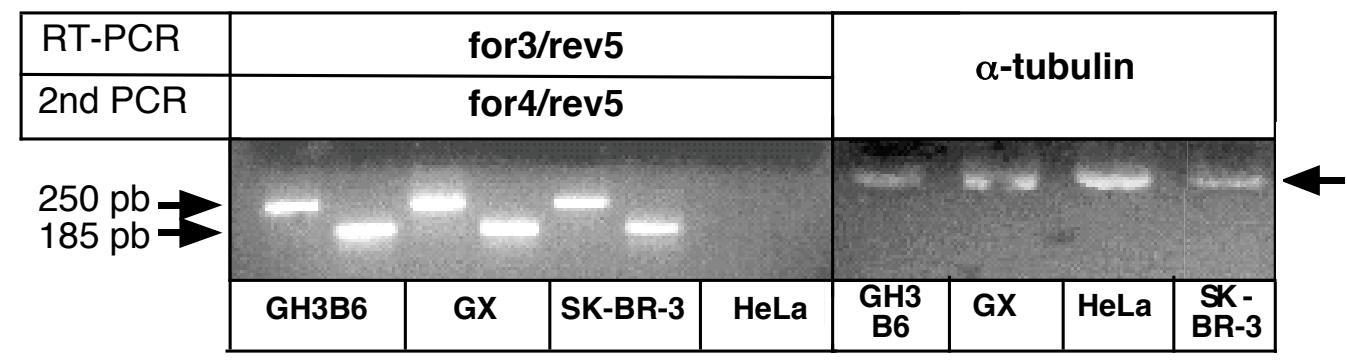

D

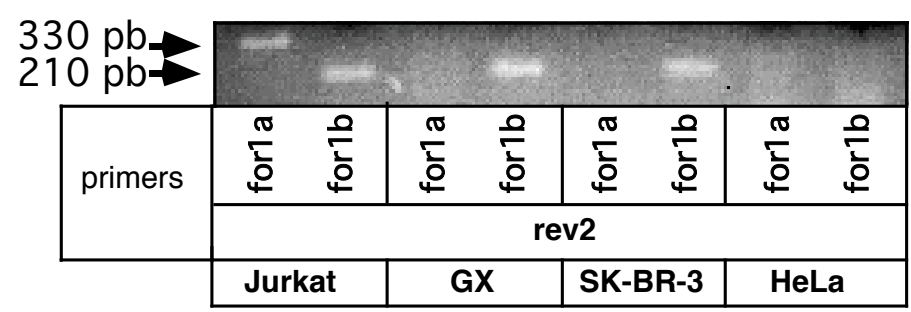

Fig. 1 
A

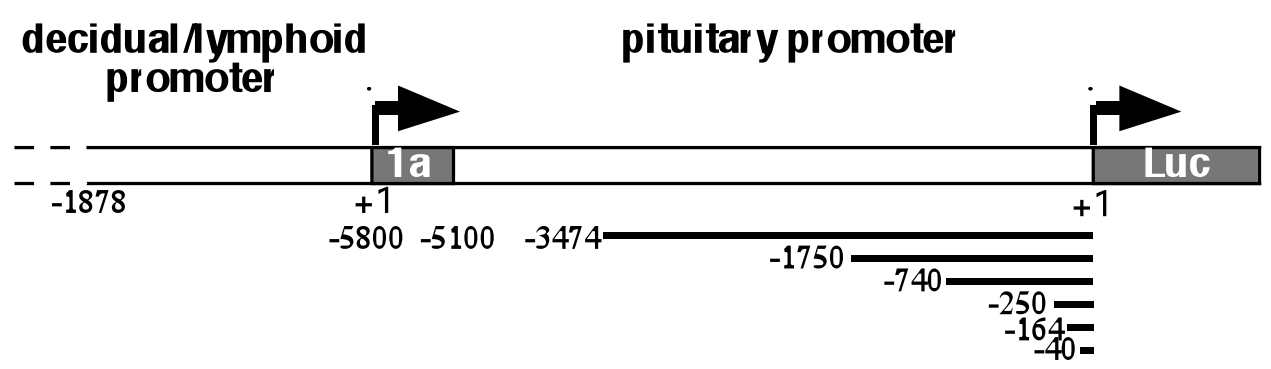

B

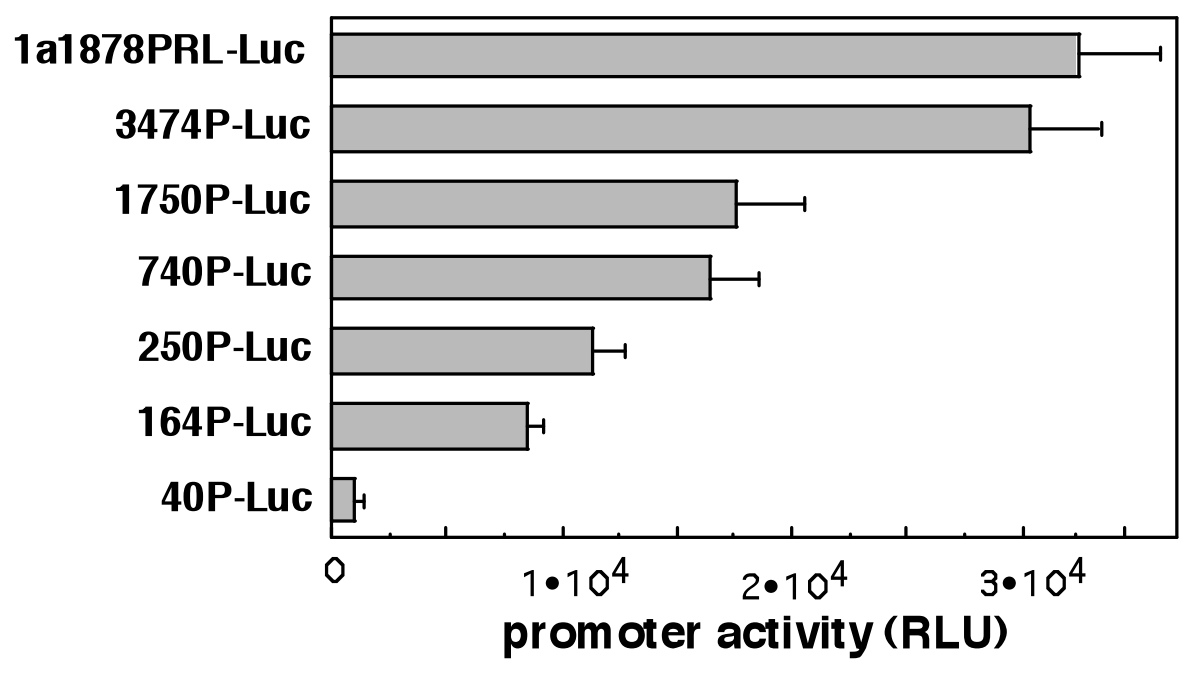

C

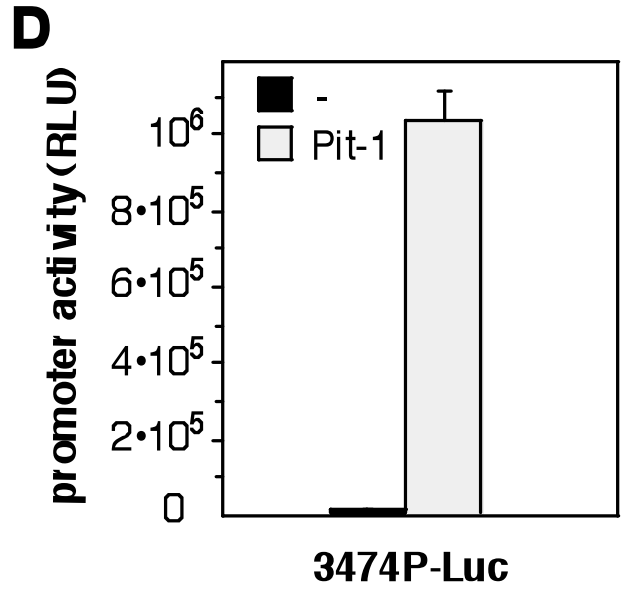

Fig. 2A, B, C , D 
E

\section{control}
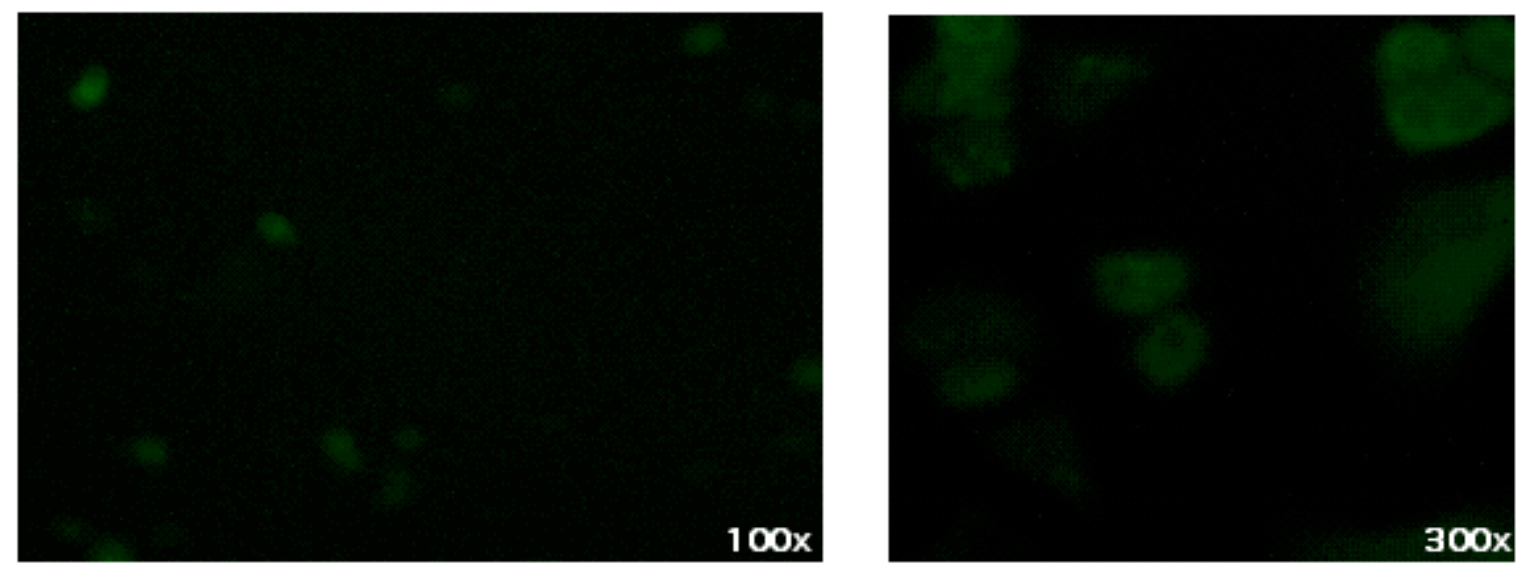

Pit-1
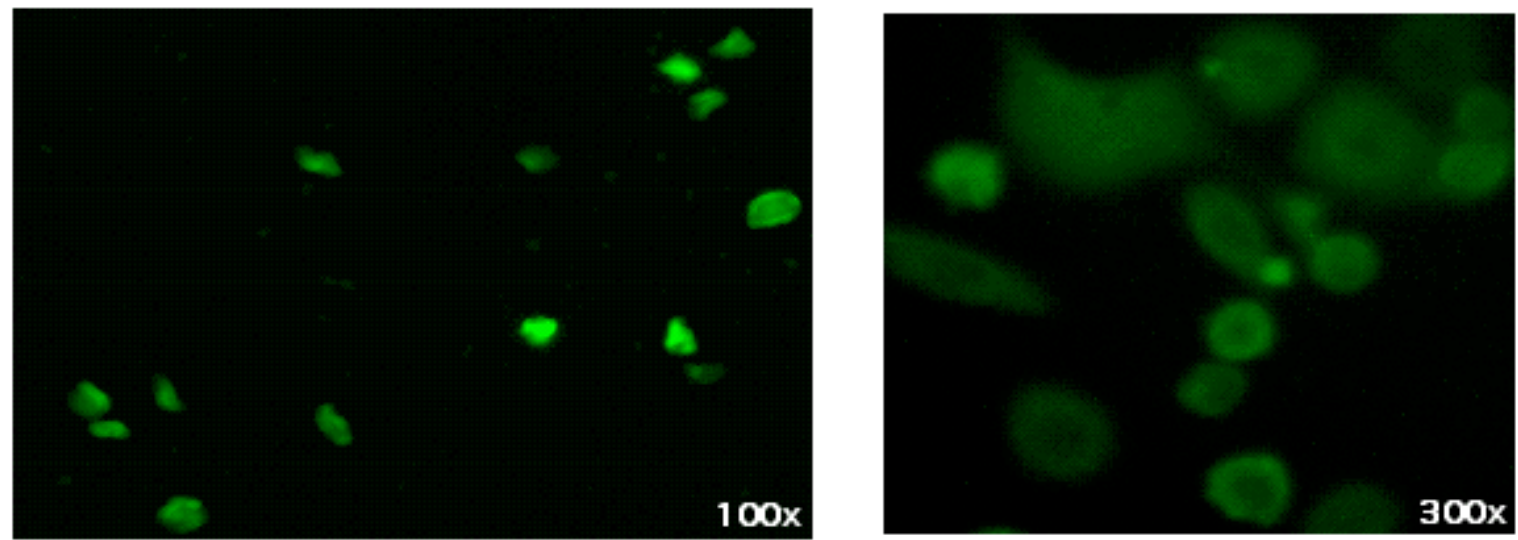

Fig. 2E 
A

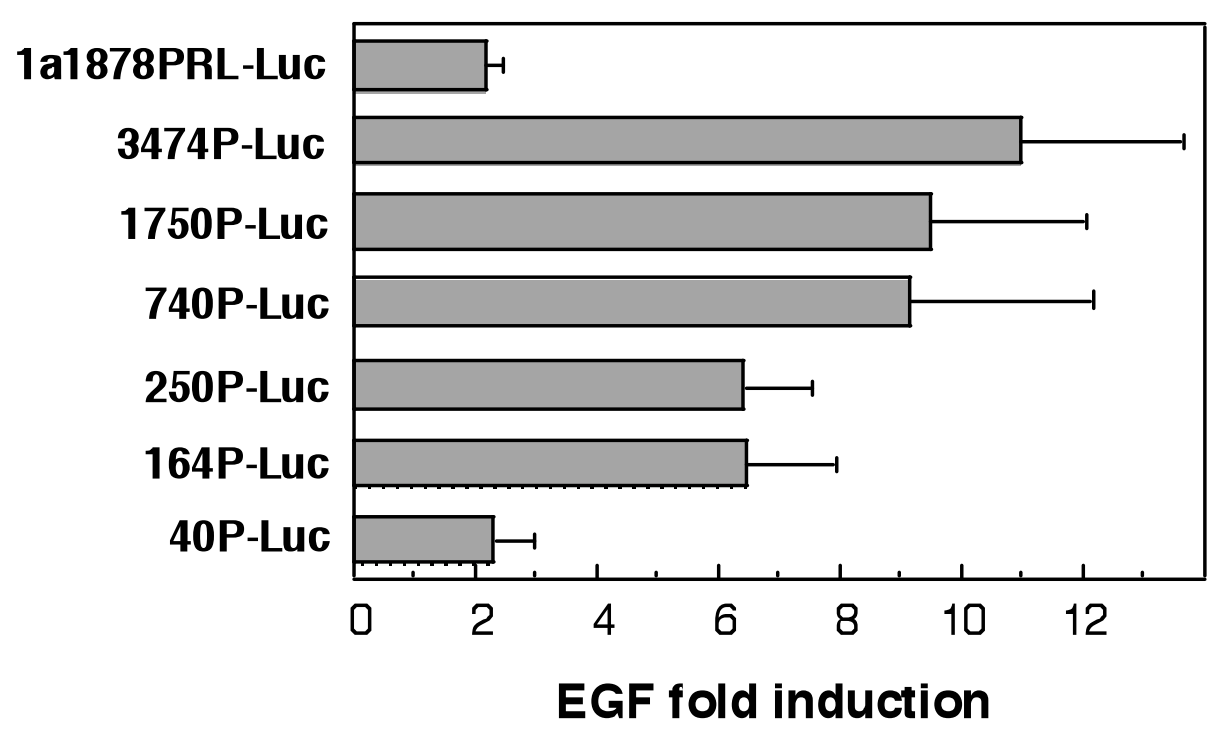

B

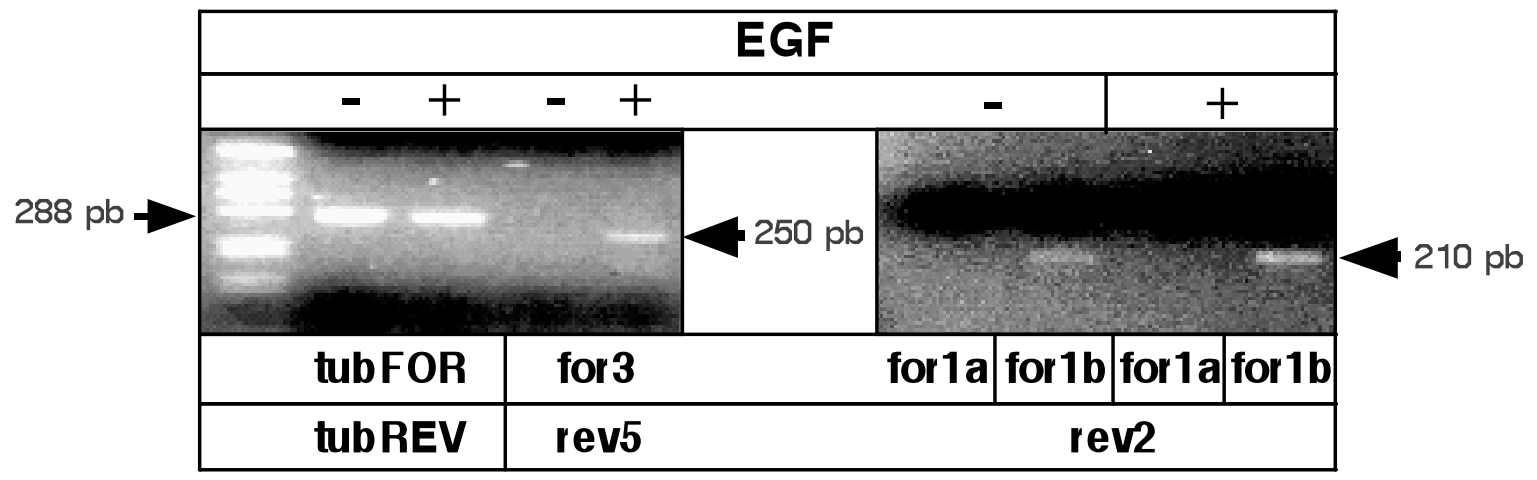

Fig. 3 
A

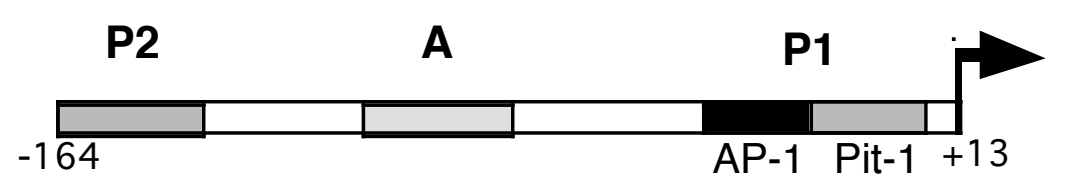

B

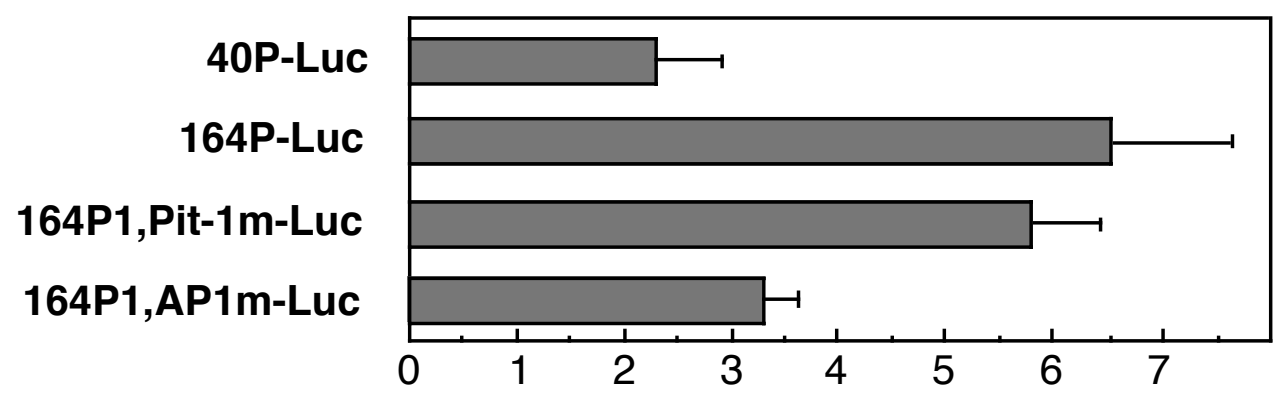

EGF fold induction

C

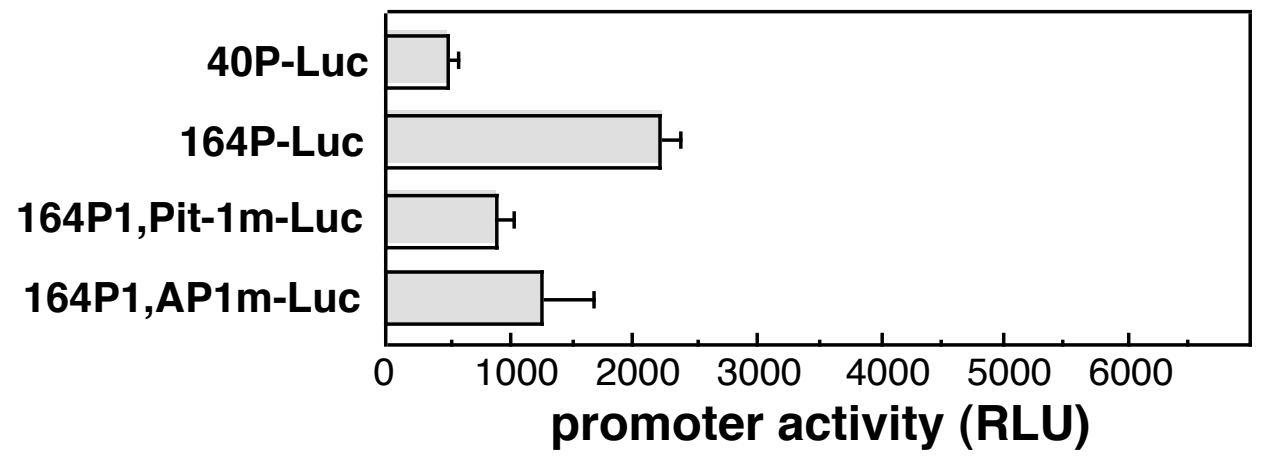

Fig. 4 
A

EGF:

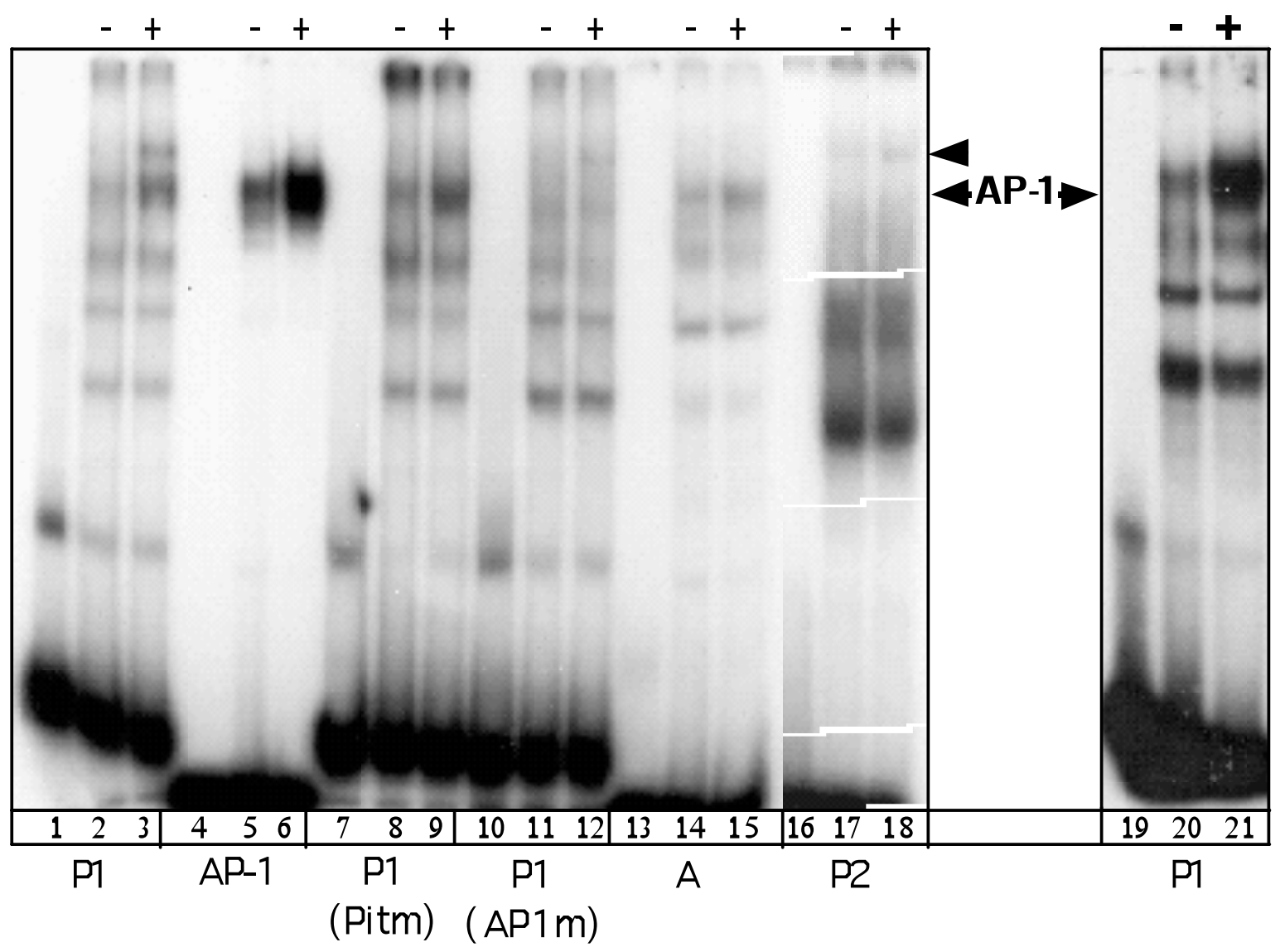

Fig. 5A 
B

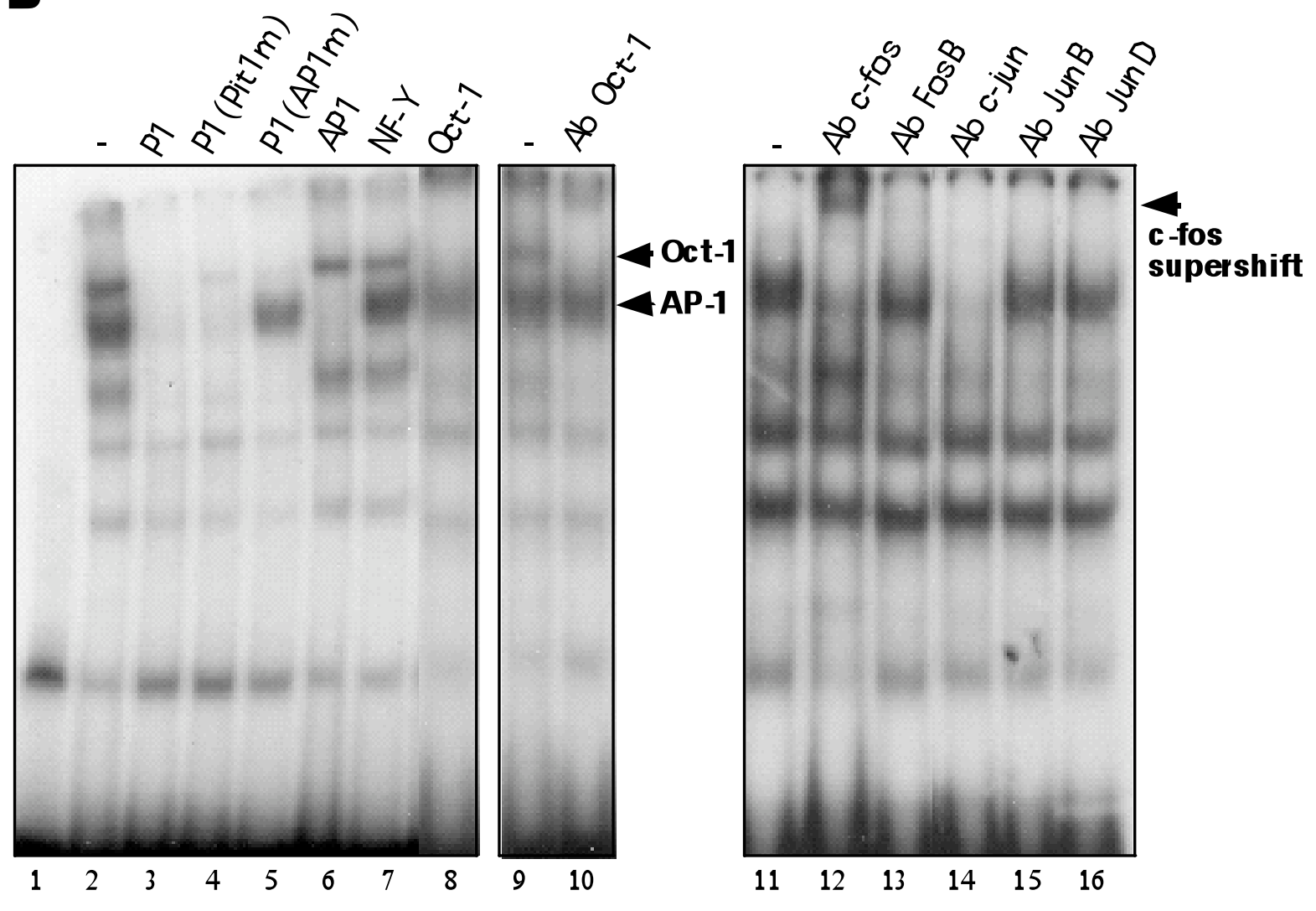

C

EGF

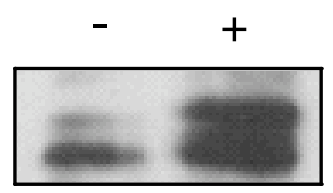

C-fos

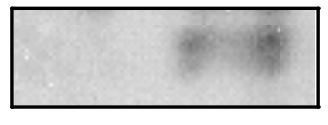

cjun

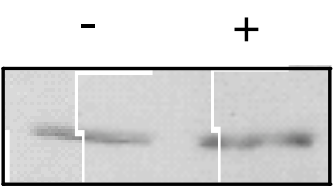

FosB

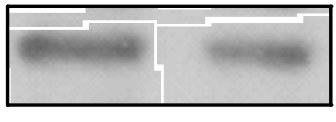

JunB

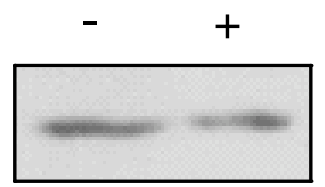

Fra-1

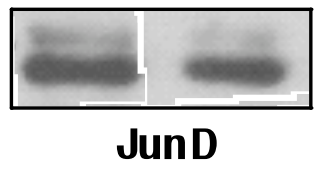

Fig. 5 BC 


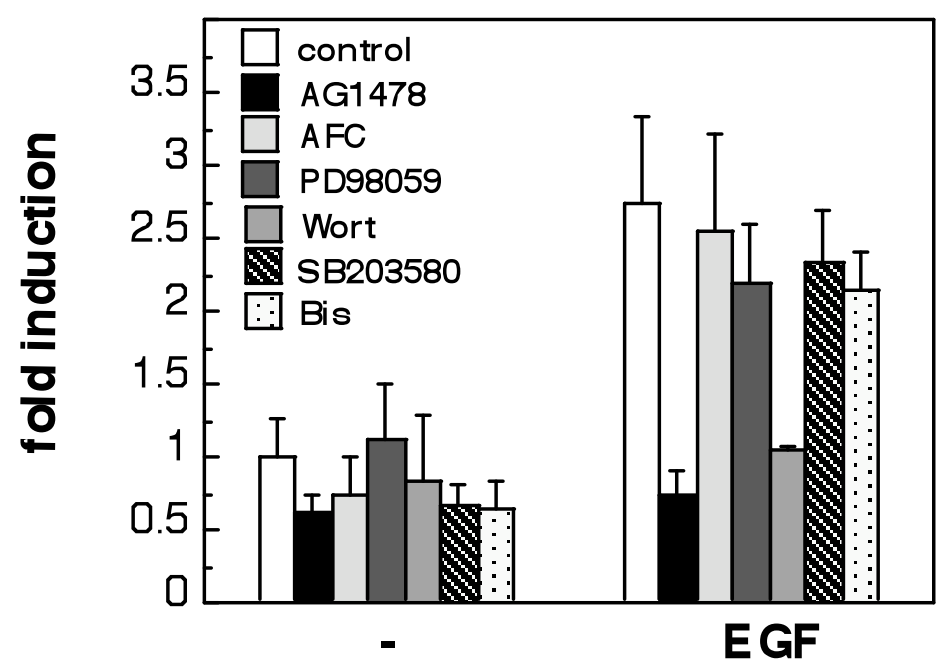

Fig. 6 


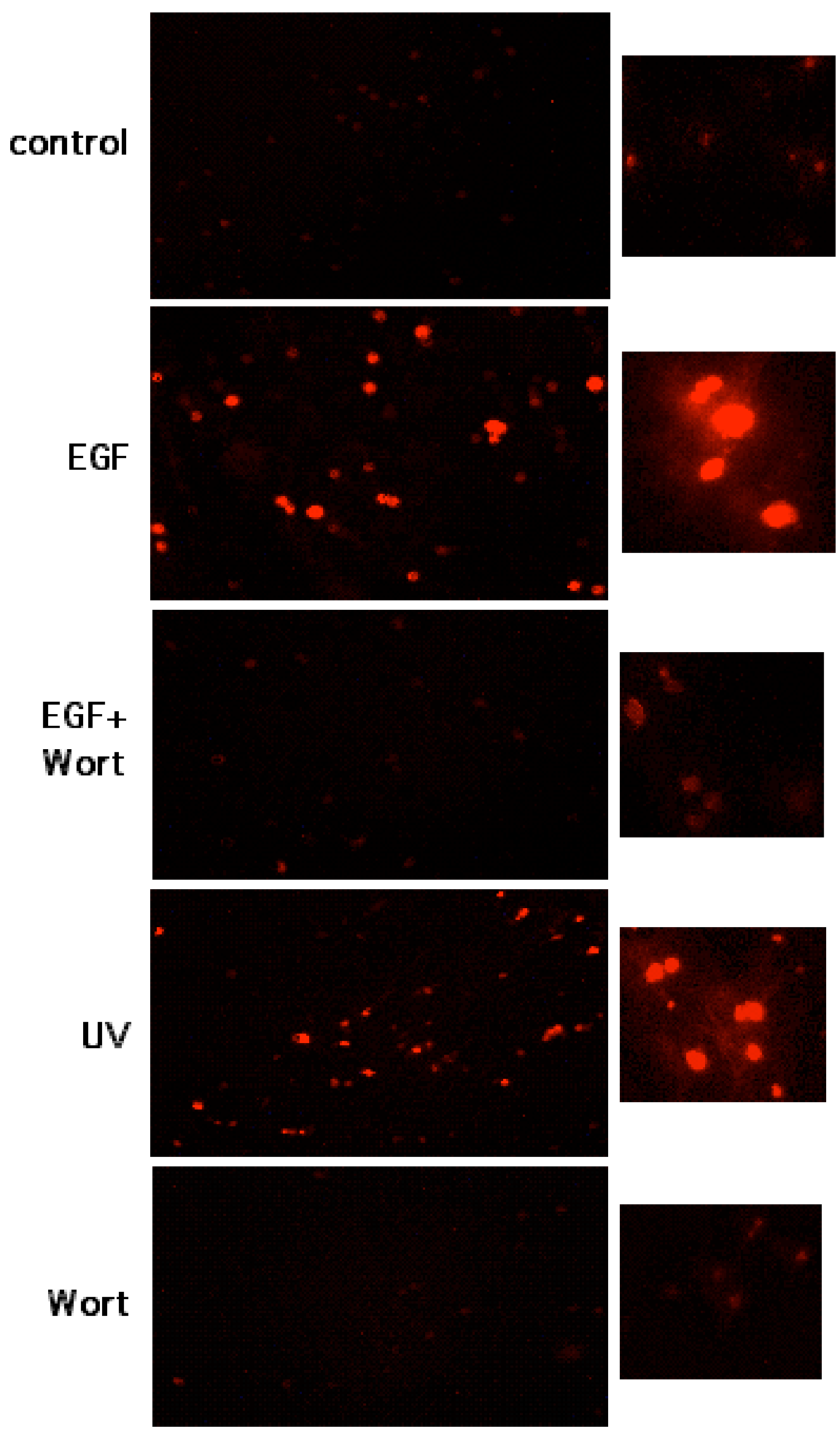

Fig. 7 